\title{
Review: \\ Microbial induced mineralization of calcium carbonate for self-healing concrete
}

\author{
WAILL A. ELKHATEEB, MARWA O. ELNAHAS, GHOSON M. DABA \\ Chemistry of Natural and Microbial Products Department, Pharmaceutical Industries Division, National Research Centre, Dokki, Giza, 12622, Egypt. \\ Tel.: +201013241936; Fax.: +20233370931, "email: ghoson.daba@yahoo.com \\ Manuscript received: 17 July 2020. Revision accepted: 2 January 2021.
}

\begin{abstract}
Elkhateeb WA, Elnahas MO, Daba GM. 2021. Review: Microbial induced mineralization of calcium carbonate for selfHealing concrete. Asian J Nat Prod Biochem 19: 1-9. Low-cost solutions achieving concrete self-healing are attracting researchers' attention. Generally, a concrete self-healing mechanism has been accomplished so far by three approaches: autogenous healing, encapsulation of polymeric material, and microbial-induced mineralization of calcium carbonate. The microbial approach seems an attractive, potent, and relatively cheap way to achieve concrete self-healing. Hence, this review elucidates the microbial concrete selfhealing mechanisms and compares the roles of fungal and bacterial mediated self-healing concrete.
\end{abstract}

Keywords: Bacteria, biotechnology, calcium carbonate, fungi, self-healing concrete

\section{INTRODUCTION}

Concrete structures are the primary elements in any infrastructure system (Ghali et al., 2018; Hassoun and AlManaseer, 2020). Concrete infrastructure suffers from cracks that are formed due to many factors, such as freezethaw cycles, drying shrinkage, delayed ettringite (hydrous calcium aluminum sulfate mineral) formation, creep and fatigue, and reinforcement corrosion (Roodman et al. 1995; Vinoth et al. 2016; Menon et al. 2019). The problem with cracks is that they significantly weaken the durability of concrete structures because they channel in water, gases like oxygen, and carbon dioxide, which could potentially corrode the reinforcement of steel (Nama et al., 2015; Bossio et al., 2017). Furthermore, cracking may promote severe degradation of the non-mechanical properties of concrete (Menon et al., 2019). However, the implementation of continuous maintenance often requires extensive work and investment. Hence, low-cost maintenance and repair of harmful cracks without onerous work have attracted researchers' attention. A significant amount of research has been conducted during the past decade to understand how these harmful cracks could heal themselves without human intervention or interference. Three approaches have so far achieved the self-healing mechanism in concrete: autogenous healing (Edvardsen 1999), encapsulation of polymeric material (Dry 1994), and biologically induced mineralization of calcium carbonate (Decho 2010; Sisomphon et al. 2012; Reddy 2013; Krajewska 2018; Žáková et al. 2019). In this field, the microbial approach has attracted serious attention (Zhu and Dittrich, 2016; Joshi et al., 2017; Chaurasia et al., 2019). The history of using microbes to solve the concrete cracks problem started when a scientist (Hendrik Marius Jonkers) was inspired by the ability of the human body to heal minor damages on its own (self-healing). From this point, the word (Bioconcrete) has seen the light to describe a type of concrete capable of healing itself naturally. Using bioconcrete in the construction and maintenance of old structures will contribute to preserving the structure of the concrete and reducing overall costs (Harshali et al., 2016; Alves et al., 2019; Castro-Alonso et al., 2019). Additionally, microbe's contributions in this field are added to the list of biotechnological applications that emphasize microbes' ability to continuously serve humanity (Daba et al., 2018; Elkhateeb and Daba, 2019; Waghmode et al., 2019; Algaifi et al., 2020). The term "microbe" refers to many different types of organisms, but research work on self-healing concrete has been so far restricted to bacteria (Achal et al., 2011; Krishnapriya and Babu, 2015; Jin et al., 2018; Ruan et al., 2019). Bacteriamediated self-healing concrete based on biologically induced mineralization processes has been extensively studied during the past decade (Dick et al. 2006; De Muynck et al. 2008; 2010; Jonkers et al. 2010; Nosouhian et al. 2016; Seifan et al. 2018). Many studies have demonstrated that bacteria are capable of precipitating calcium carbonate, which possesses high compatibility with concrete compositions, and this precipitation step is conducted via various biologically induced mineralization processes (Stanaszek-Tomal and Kozak, 2017; Wang et al., 2012; Ersan et al. 2015; Khaliq and Ehsan 2016; Seifan et al. 2016; Zhang et al. 2017; Gautam 2018).

The major technique employed to make bacteriamediated self-healing concrete, spores of bacteria spores and their nutrients, are supplemented to the concrete matrix during the concrete mixing process. Later, cracks appear in concrete due to many reasons, and water comes in contact 
BIOFARMASI J NAT PROD BIOCHEM 19 (1): 1-9, June 2021

with the dormant bacterial spores existing in the concrete mixture from the beginning. As a result, the bacterial spores grow and precipitate calcium carbonate to treat concrete cracks in situ. Then after full self-healing of cracks and consumption of all water inside, bacteria return to dormancy again. For old structures where bacterial spores were not mixed from the beginning with a concrete mixture, injection or spraying bacterial spores and their nutrients into the cracks are the techniques used to deal with that case (Pal et al. 2020). On the other hand, fungi appear as the potent perfect candidate for this mission (Martuscelli et al. 2020). Interestingly, many studies have also reported the microbial approach's ability to improve the physicomechanical characteristics of concrete, cement, and mortar (Abo-El-Enein et al., 2013; Sharaky et al., 2018; Girometta et al., 2019).

Microbial $\mathrm{CaCO}_{3}$ has the advantage of being environmentally friendly; also, it is an economical material that could find promising and potential applications in the engineering field. It could protect the concrete and stone surfaces. Also, it could repair the developed flaws and defects and reduce the consolidation of loose particles (Cheng and Cord-Ruwisch 2012; De Muynck et al. 2008; Van Tittelboom et al. 2010; Wang et al. 2012). This review described microbial concrete self-healing by comparing fungal and bacterial mediated self-healing concrete roles.

\section{Bacterial concrete healing}

It is known that the lifetime of the concrete structures is negatively affected by several factors that lead to the formation of micro-cracks followed by the entrance of different materials, such as carbon dioxide, water, chlorine ions, etc., into these cracks. Finally, the results are corrosion and degradation of the concrete, which will need regular and expensive repairs as well as many maintenance works. Moreover, it is difficult to avoid further cracking in reinforced concrete due to many factors, including earlyage shrinkage, thermal effects, mechanical loading, or it could be a combination of more than one factor (De Rooij et al. 2013; Isaacs et al., 2013).

Nowadays, several studies aim to find an economic bacterial-originated self-healing concrete in order to reduce the needed repair and maintenance of concrete structures. Autogenous concrete self-healing depends mainly on the concrete composition, and the substantial damage could be protected by the hydration reaction of the cementitious materials within the concrete structure. About $15-25 \%$ of the cement is found in an un-hydrated form in the concrete matrix, so once cracking occurs, these exposed un-hydrated cement grains will start to absorb water, and the hydration process will start, which in turn fills up and heals the developed cracks. This self-healing process is known as autogenous healing. This process could be efficient but only for very narrow cracks (Ter Heide 2005; Ter Heide and Schlangen 2007).

$$
\begin{aligned}
& \mathrm{CaO}+\mathrm{H}_{2} \mathrm{O} \rightarrow \mathrm{Ca}(\mathrm{OH})_{2} \\
& \mathrm{Ca}(\mathrm{OH})_{2}+\mathrm{CO}_{2} \rightarrow \mathrm{CaCO}_{3}+\mathrm{H}_{2} \mathrm{O}
\end{aligned}
$$

Bacterial spores have gained great importance in selfhealing due to their ability to precipitate calcium carbonate. However, these spores show some drawbacks, including a short lifetime due to the presence of an alkaline medium as well as shrinkage of spores (Jonkers et al. 2010; Jonkers 2007). Cracks with widths up to $0.5 \mathrm{~mm}$ could be healed with these spores (Rao et al., 2013). The bacterial spores have the ability to be capsulated and incorporated into the concrete, which induces the concrete healing ability (Jonkers et al. 2010). When the weather gets humid, the bacteria become activated and start to reproduce, and then they will germinate in the calcium lactate. After that, the bacteria combine with the carbonate ions, and finally, insoluble calcium carbonate is formed, which is responsible for filling the cracks (Ramachandran et al. 2001). This process is known as Microbial Induced Calcium Carbonate Precipitation (MICCP), also known as Bio-mineralization (Kavia and Hema 2015).

After the bacterial activation process, many metabolic processes occur, including photosynthesis, sulfate reduction, and urea hydrolysis, which cause the formation of by-products, including calcium carbonate. Bacillus species represent the mineralized microorganism that is widely used in bio concrete. Under unfavorable conditions, Bacillus species form dormant spores that can resist several bactericidal factors such as heat, alkali, dryness, and organic solvents (Setlow 1994).

Various bacteria play an important role in calcium carbonate precipitation. Among these bacteria, we can mention Bacillus cohnii, Bacillus halodurans, Bacillus pasteurii, Bacillus pseudofirmus Bacillus sphaericus, Bacillus subtilis, etc. (Figure 1) (Vijay et al. 2017). Many factors affect the precipitation process, such as calcium concentration, the concentration of dissolved inorganic carbon, pH as well as nucleation sites (Jonkers 2011). Another important factor is the ability of the bacteria to utilize the organic nutrients and convert them to inorganic calcite crystals (insoluble), which in turn fill the concrete cracks (De Rooij et al., 2013).

The spray drying method was employed to obtain a huge amount of bacterial powder needed for concrete production. The produced-enriched bacterial solution was added to the spray dryer, where the bacterial solution was produced as a liquid droplet by atomization. Then rapidly, under high temperatures, it dries inside the spray dryer to finally form a powdery material. These steps cause the bacterial vegetative cells to be transformed into spores due to the presence of unfavorable conditions (high temperature and dryness), and the final obtained product is microbial spore powder (Zhang and Qian 2020).

Immobilization of the bacterial strain on polyurethane and spore formation techniques are gaining great attention in bonding the formed cracks in the concrete. Where the bacterial carbonate precipitation is produced due to the ureolytic activity as well as the bio-mineralization of the bacteria. In the presence of a calcium source, the bacterial strains are able to precipitate calcite through producing urea. The bacterial strains are added to the concrete along with calcium sources, phosphorous, and nitrogen 
components. These ingredients may stay in the concrete for up to 200 years.

\section{Effect of bacteria on concrete criteria}

It was reported that the bacterial metabolic activity occurring in concrete improves concrete performance overall, including compressive strength (Saifee et al., 2015). Other studies found that the compressive strength increased significantly by $42 \%$ upon applying 105 cells $/ \mathrm{mL}$ concentration and increased the tensile strength by about $63 \%$ after 28 days of treatment (Saifee et al., 2015). It was also found that concrete mass loss due to acid exposure was greatly reduced upon the microbial treatment.

Concrete water absorption ability was also evaluated, and the results showed a smaller mass increase for bacterial concrete compared to the control untreated concrete. Assuming that the bacterial concrete shows less porosity (Stanaszek-Tomal 2020). Moreover, introducing bacteria to the concrete also decreases the mass loss upon exposure to chloride and improves its compressive strength (Ravindranatha et al., 2014).

Bacillus pasteurii was added to concrete, and the results showed an increase in the initial strength of concrete. Moreover, the Bacillus subtilis strain was used in biological concrete since this strain is able to survive in extreme temperatures (from $30{ }^{\circ} \mathrm{C}$ up to $700{ }^{\circ} \mathrm{C}$ ) (Manikandan and Padmavathi 2015), and also, an obvious increase in the concrete compressive strength was detected (Jagadeesha Kumar et al. 2013). Bacillus flexus, a bacterial strain that is not reported as calcite precipitating, also shows high compressive strength (Jagadeesha Kumar et al., 2013).

The bacteria can be introduced into the concrete using vascular systems or capsules. Some industrial by-products, including fly ash and silica fume, could replace the cement in concrete in order to reduce the porosity in concrete. The silica fume has the advantage of being porous and very fine and thus exhibits high bonding strength, which makes concrete denser and reduces the concrete permeability (Morsali et al. 2019). It was reported that replacing cement with other recycled or natural products helps in reducing the amount of cement content used in concrete, which helps decrease Co emission in the cement manufacturing process.

Various inorganic porous materials have been used by researchers recently (Alazhari et al. 2018), such as materials are graphite nano-platelets (Khaliq and Ehsan 2016), ceramsite (Chen et al. 2016), lightweight aggregates (Chen et al. 2019; Zhang et al. 2017), hydrogel (Wang et al. 2014), zeolite (Bhaskar et al. 2017), polyurethane, glass tubes (Wang et al. 2010), as well as expanded clay particles or expanded perlite (Jiang et al. 2020). These porous materials are employed as carriers protecting the bacteria from the concrete unfavorable alkaline environment. A suitable environment is created inside the pores that help bacteria grow safely. A study was reported where the sugar coating was used in order to immobilize both nutrients and bacteria (Jiang et al. 2020).

Some researchers applied Bacillus pasteurii bacteria with rice husk ash (15\%) as well as micro-silica (10\%) into the concrete. The results showed an increase in bacterial strength by $21 \%$ comparing to the control sample (at $10^{5}$ cells/mL and after 28 days) (Ameri et al., 2019). Since the nanomaterials are well established in many studies, some researchers use nanoparticles or microparticles of iron oxide or bentonite, which aid in immobilizing the bacteria (Shaheen et al., 2019). It was found that bacteria immobilization with iron oxide-based media was able to heal concrete cracks with widths up to $1.2 \mathrm{~mm}$, and the compressive strength markedly increased to $85 \%$ of that of the control samples. However, bentonite immobilization resulted in cracks healing with widths up to $0.15 \mathrm{~mm}$ and $0.45 \mathrm{~mm}$, where the compressive strength increased by $45 \%$ and $65 \%$, respectively c,ompared to the control sample.

The microbial self-healing concrete is applied mainly at the sluice chamber bottom plate as well as at the junction of the side walls. The cementitious materials produce a huge amount of hydration heat during the hydration process, where the concrete internal temperature increases sharply (Ataie 2019). On the other hand, the outer surface of the structure loses heat so fast, creating an obvious temperature gradient through the sidewall (Yang et al. 2016). The difference in temperature between internal layers and the surface of the concrete resulted in shrinkage and, finally, damage to the concrete surface due to the formation of cracks (Yang et al. 2019). Besides, the bottom plate was placed before the sidewall, leading to a restriction of the free contraction of the newly poured concrete (of the sidewall). That's why microbial self-healing concrete is added to this part.

These bio-concrete exhibit many advantages. Applying bio-concrete significantly increases the strength of concrete. It also provides effective resistance to freezethaw conditions and reduces the corrosion and permeability properties compared to conventional concrete. Besides the economic advantage as it reduces the repairing and maintenance costs. On the other hand, the bio-concrete may show some drawbacks, where some of the used bacteria that grow in concrete may be harmful for atmosphere and human health. So its usage is limited to some structures. Also, the cost of this kind of concrete is high comparing to the conventional concrete (about 7-28\% more than conventional concrete) (Kumari 2015). The durability of bio-concrete depends on many factors. The bacterial strain itself is considered the most important factor that affects the strength of the concrete. The studies showed that Bacillus subtilis increases the concrete strength by $6.42 \%$ and $9.16 \%$ after being used for 7 days and 28 days respectively, however, Bacillus pasteurii was found to increase the strength by $29.99 \%$ and $29.97 \%$ after 7 days and 28 days, (Bashir et al. 2016) respectively.

Bacillus sphaericus showed the highest concrete strength where the strength of the concrete increased by about $65.93 \%$ and $52.42 \%$ for 7 days and 28 days respectively. Other studies reported the effect of Bacillus cereus and Bacillus pasteurii on cement mortar compressive strength and it was observed $38 \%$ and $28 \%$ strength increment respectively (Maheswaran et al. 2014). Moreover, Sporosarcina pasteurii shows compressive strength of $38.2 \mathrm{MPa}$ and $44 \mathrm{MPa}$ for 28 days and 91 days 
respectively (Chahal et al. 2012) however incorporating Bacillus pasteurii exhibit no negative effect on concrete hardened properties (Gavimath et al. 2012). Applying Shewanella in bio-concrete shows positive potential and compressive strength was increased by $17 \%$ and $25 \%$ after 7 and 28 days respectively. Nevertheless, Escherichia coli shows no effective change in the compressive strength upon incorporation in bio-concrete (Ghosh et al. 2005). In conclusion, selection of microorganisms is considered a critical factor to alter the concrete properties (Ghosh et al. 2005).

Moreover, comparing to the control concrete, the chloride penetration and water permeability decrease significantly (Li et al. 2012), after the concrete bioremediation by applying Bacillus pasteurii and Bacillus cereus (Maheswaran et al. 2014). It was reported that incorporating Bacillus halodurans Strain KG1 in the concrete mix resulted in a decrease in the porosity and water absorption $12.4 \%$ and $20 \%$ at 91 days respectively (Kunal et al. 2016), plus an obvious increase against water penetration and other hazardous materials was reported (Senthilkumar et al. 2014). The studies also showed that Bacillus sphaericus addition to the concrete mix improves its strength against permeability as a result of bio deposition (Basheer and Cleland 2011; Basheer et al. 1997). Another advantage of bio-remediated concrete is its capacity to resist chloride penetration which in turn decrease corrosion rate of reinforcement (Dai et al. 2010; Ibrahim et al. 1997; Medeiros and Helene 2009). it was also reported in another article that Bacillus pasteurii reduces chloride permeability, porosity, and water absorption, and interestingly the incorporation of bacteria in the concrete mix reduces the capillary absorption capacity by about $20 \%$ compared to control mix (Giannaros et al. 2016).

Cement-based concrete together with added and GGBFS (ground granulated blast furnace slag) and silica fume was found to increase the compressive strength where the mixture containing about 35\% GGBFS exhibits a compressive strength of $56 \mathrm{~N} / \mathrm{mm}^{2}$ (Depaa and Kala 2018). And the mixture reached its maximum strength $\left(37 \mathrm{~N} / \mathrm{mm}^{2}\right)$ with an addition of $12.5 \%$ of silica fume resulted in increasing the strength $\left(37 \mathrm{~N} / \mathrm{mm}^{2}\right)$. The compressive strength of concrete was greatly enhanced to reach the maximum value at a cell concentration of $10^{5} / \mathrm{mL}$ (Reddy et al. 2015). Other studies showed that $5 \%$ of bacterial additives together with calcium lactate were employed in microbial concrete and resulted in improving the concrete compressive strength to be $49.5 \mathrm{MPa}$ at 28 days (Babu and Siddiraju 2016).

Bacillus pasteurii was also cultured on a medium modified with the addition of calcium chloride and urea (Ramakrishnan et al. 1999). The compressive strength of cement mortar was reported to be $65 \mathrm{MPa}$ for 28 days where that of the control mortars was $55 \mathrm{MPa}$, without the addition of any bacterial cells. The authors observed an improvement in compressive strength in mortars as it increased by $17 \%$ for 7 days, and by $25 \%$ for 28 days (Ghosh et al. 2005).

\section{Cost for bacterial concrete production}

Some studies focus on the cost of applying microbial concrete comparing to the utilization of conventional concrete (Vekariya and Pitroda 2013; Reddy et al. 2015; Dinesh et al. 2017). It was reported that the cost of microbial concrete is about 2.3 to 3.9 times higher than that of conventional concrete. The reason for this high price is that the cost of bacteria and the required nutrients consumed to develop the material account for about $80 \%$ of raw materials cost.

Some nutrient ingredients such as cheap industrial wastes (lactose mother liquor produced from starch industry or liquid corn) that contain high amount of protein content have been used in order to reduce the cost of bacterial concrete production (Jonkers 2007). Using these materials significantly reduces the price of the production. Moreover, the self-repair capability of the bacterial concrete that results in extending the building life and hence reducing the total cost is not recognized by the investors.

The majority of the contractors provide buildings warranty for nearly 10 years and during this period of time, few cracks were observed. Thus, the advantages and benefits got from using bacterial concrete might not be touched for many years that could be more than ten years. This reason results in discouraging the contractors to use this bacterial concrete. However, the benefits of using selfhealing concrete are definitely beyond any economic advantages (Silva et al. 2015). More studies are required to reduce the cost of culturing bacteria that will lower the initial cost, and this will attract the attention of the contractors.

\section{Why fungi are the perfect candidates used for self- healing concrete}

One of the major obstacles facing the use of bacteria in calcium mineral precipitation is the limited ability of the majority of bacteria to survive and resist the extreme environment in concrete such as high alkalinity, varied temperature, and dry condition of concrete (Seifan et al. 2016). So far there has been little success with respect to the long-term healing efficacy and in-depth consolidation, mainly due to the limited survivability and carcinogenic ability of the bacteria, and the recorded viability of bacterial spores embedded in concrete did not exceed six months (Jonkers 2011). Due to the above-mentioned, further screening for other types of microorganisms having the ability to catalyze calcium mineral precipitation becomes of great potential importance (Luo et al. 2018). 


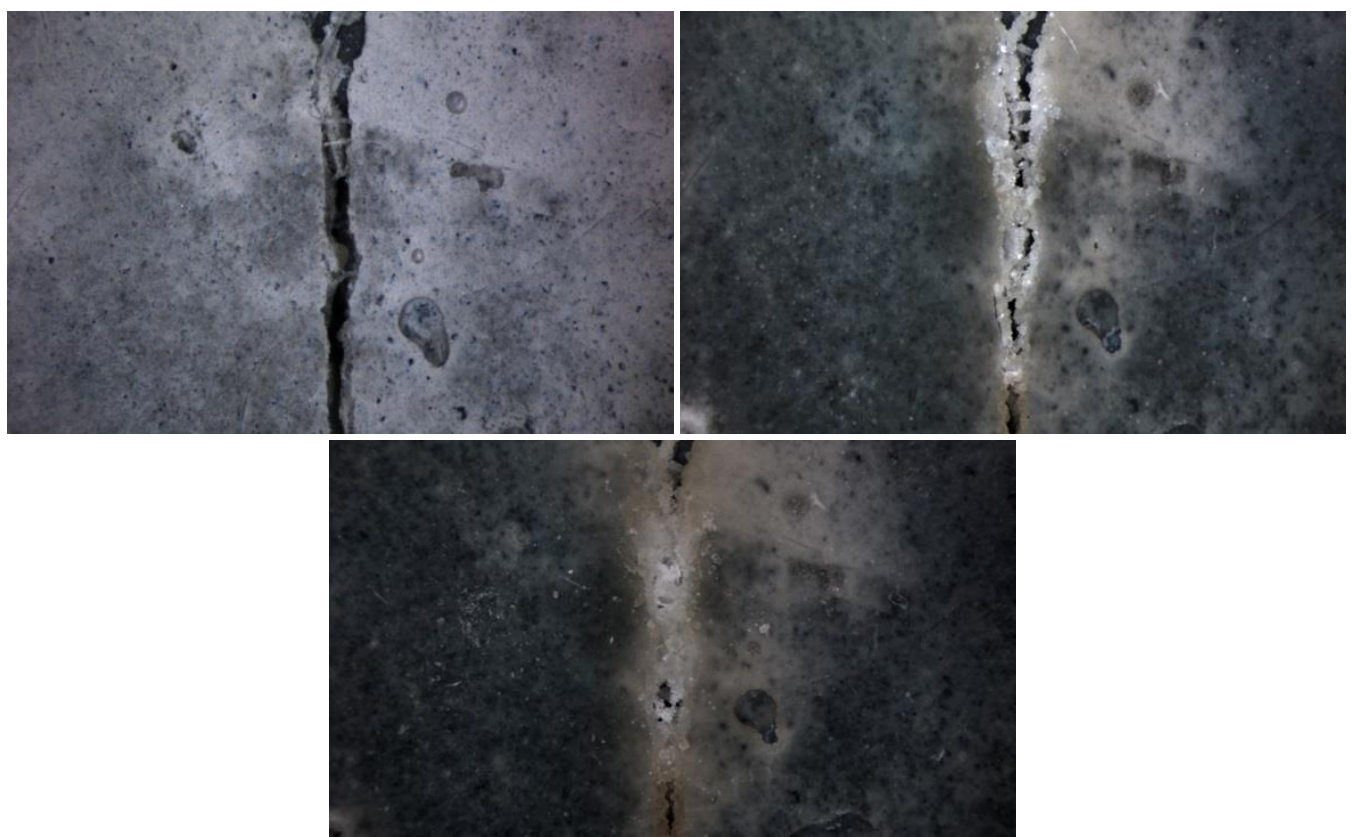

Figure 1. Bacterial self-healing concrete at different stages (hosted by https://www.thestructuralengineer.info)

Fungi could be one of the best candidates to be used as self-healing agent due to many reasons. First of all, filamentous fungi grow as threadlike structures called hyphae which grow to create an intertwined 3D network called mycelium which acts as biological fiber that improves the physicomechanical characteristics of bioconcrete (Martuscelli et al. 2020). Also, filamentous fungi have higher surface-to-volume ratios, and hence possess a larger fraction of organic substrates available for mineral precipitation (Menon et al. 2019). Moreover, fungi can survive in metal-polluted environment (Dias et al. 2002). The fungal mediated self-healing concrete possesses long term self-healing capacity that heals wider cracks within shorter periods of time. Beside, fungal spores and nutrients, could lead to no negative consequences on concrete compressive strength (Jin et al. 2018; Menon et al. 2019). Fungi can also promote large amount of calcium carbonate precipitates within short periods of time (Rautaray et al. 2003; 2004; Ahmad et al. 2004; Luo et al. 2018).

Generally, fungal mineral precipitation is conducted through induced biomineralization and organomineralization processes (Menon et al. 2019). There are two critical factors influencing the amount of produced Calcium carbonate which are $\mathrm{Ca}^{++}$concentration, and carbonate alkalinity (Bindschedler et al. 2016). Many fungal metabolic activities can increase carbonate alkalinities such as physicochemical degassing of fungal produced $\mathrm{CO}_{2}$, water consumption, oxidation of organic acids, nitrate assimilation, and urea mineralization (Menon et al. 2019). On the other hand, fungal metabolic activities can also affect the concentration of calcium ions. Regulation of calcium ions concentration within fungal cells takes place by keeping $\mathrm{Ca}^{++}$concentrations sufficiently low in the cytoplasm by pumping it out of the cell or by binding it onto cytoplasmic proteins (Bindschedler et al. 2016).

Mechanism of calcium ions precipitation is a way to protect fungal cells from the calcium-rich environment characterizing concrete, which represents stress for fungal cells due to cell toxicity by high concentrations of calcium ions and subsequent osmotic pressure. To decrease the internal calcium ions concentrations, fungal cells produce oxalic acid which converts calcium ions to calcium oxalates (Neville 1996; Verrecchia 2000). Precipitation of Calcium carbonate may be due to a similar passive mechanism to immobilize excessive calcium ions. Similarly, high alkalinity represents stress on fungal cells that are faced by precipitating Calcium carbonate to protect the fungus intracellularly (Figure 2). The cell walls of fungi contain chitin which can bind calcium ions. Interestingly, both living and dead fungal biomass can bind ions onto their cell walls, then bound calcium ions can interact with the dissolved carbonate, resulting in precipitation of calcium carbonate on the fungal hyphae which means that fungi could be used as self-healing agents. Besides being an eco-friendly process, the application of microbial precipitation of $\mathrm{CaCO}_{3}$ by urea hydrolysis fills cracks in concrete as a surface solution to cracks problem, or as an integrated curative agent. This type of treatment will ensure no need for future repair or inspection, which promotes increased durability of the structure, and decrease overall cost of maintenance (Mamo and Mattiasson 2019; Martuscelli et al. 2020).

Preliminary laboratory investigations to evaluate fungal ability to precipitate calcium carbonate is focussing usually on placing the fungus under investigation onto cured concrete plate then observe change in $\mathrm{pH}$ (increase) resulting from the ability of the fungus to dissolve $\mathrm{Ca}$ $(\mathrm{OH})_{2}$ from concrete. Analyses such as X-ray diffraction 
(XRD) and scanning electron microscope (SEM) are usually conducted to visualize mycelial growth and confirm that the crystals precipitated on the fungal hyphae were composed of calcite (Luo et al. 2018; Sheir et al. 2020). Some of the important criteria that control choosing fungi in concrete self-healing to make sure that the chosen alkaliphilic fungus can be easily cultured and could survive in the extreme environment of concrete, also to be not pathogenic to human or animals health (Qian et al. 2019; Sidiq et al. 2019). Also, it is better to choose fungus showing high ureolytic activity (Kumari et al. 2016; Bhina et al. 2019). Many fungal species have been reported as promising bio-based self-healing concrete such as Aspergillus niger (Sayer et al. 1997); Serpula himantoides (Gharieb et al. 1998); Paecillomyces lilacinus, and Chrysosporium spp. (Magan 2007); Neurospora crassa (Li et al. 2014); Pestalotiopsis sp. and Myrothecium gramineum (Li et al. 2015); Trichoderma reesei (Luo et al. 2018); Aspergillus nidulans (Menon et al. 2019). Besides the previously mentioned optical analyses, Many techniques are used in order to evaluate concrete selfhealing efficiency including measuring concrete stiffness, strength, and durability (Kang and Zhongxian 2012). Water and gas permeability, and absorption tests are also used for this purpose (Huang and Ye 2015). However, it is not easy to know the appropriate strength of concrete because it depends on the material structure as well as the mechanical reactions in concrete composites.

Interestingly, the reported role of fungi in the biomineralization process extends also to calcite, metals, and sand (Bindschedler et al. 2016; Oggerin et al. 2016; Povedano-Priego et al. 2017; Fang et al. 2018; Pasquale et al. 2019).

\section{Future suggestions}

The production of self-healing concrete is an interesting point that attracts the attention of many scientists. This review aims to refer to the previous researches that show the production methods of the self-healing concrete as well as dealing with some of the problems that face the production methods.

It was mentioned previously that the self-healing ability is based on placing some materials inside the concrete structure during its production process and which resists further damage. The key in this repairing process is the activation of the added repair materials and this activation initiates under stress when the concrete is subjected to stress. The self -repair could be active or passive. The active self-repair occurs as a result of an external activation for the used repair material, such as activation due to heating effect. On the other hand, the passive self-repair process is due to an automatic reaction to an external agent and it takes place without any human intervention (Łukowski and Adamczewski 2013).

Many studies show that there is great progress in producing these materials. Bacterial and other additive modification leads to very promising results. This was proved in concrete with nano- $\mathrm{TiO}_{2}$. And it was found that it is sufficient to apply bacterial concrete only as topping plaster or a coating. Nowadays, many studies are conducted using bacterial concrete in repair concrete or mortar spraying (Sisomphon et al. 2012).

Although microbial concrete greatly improves the building materials quality, it is not found to be used on an industrial scale. This return to the difficulty in predicting future technology for these new materials. Many problems that are facing the bacterial concrete have been discussed by Saifee et al. (2015).

Many of the problems have been solved by many scientists who are almost reaching to promising solutions for these problems. Nevertheless, the problem of dealing with harmful bacteria is still needs more effort to find more safe strains that could be harmless to human health. Plus, there is not enough research about the durability of these materials nor biological cement environment effects that could occur upon biological corrosion. So future studies are needed to answer many questions such as does the produced calcium carbonate protects the used materials, and to what extent it would affect the growth of other microorganism's spores that are dispersed in air?

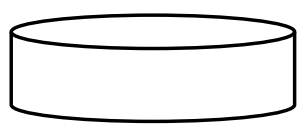

Concrete (Rich in $\mathrm{Ca}^{++}$)
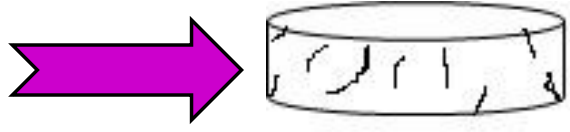

Cracked concrete

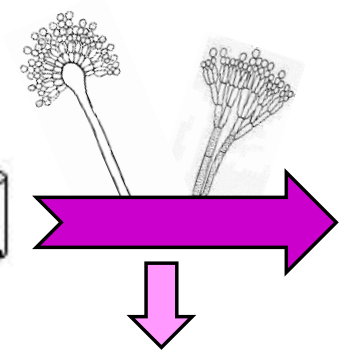

Produce organic acids

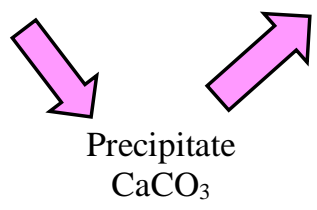

Figure 2. Schematic representation showing fungal self-healing concrete 


\section{CONCLUDING REMARK}

Bacterial and fungal-mediated self-healing concrete based on biologically induced mineralization processes has been extensively studied during the past decade, but it still has important limitations. Fungi, as one of the best candidates to be used as self-healing agents due to their superior ability to adjust to the deleterious environment of concrete and extraordinary capability to promote calcium mineralization, should no longer be deserted. Also, investigation on fungi-mediated self-healing concrete is urgently needed. On the other hand, genetic engineering techniques should be employed to improve properties of promising strains capable of participating in microbial selfhealing concrete.

\section{REFERENCES}

Abo-El-Enein SA, Ali AH, Talkhan FN, Abdel-Gawwad HA. 2013. Application of microbial biocementation to improve the physicomechanical properties of cement mortar. HBRC J 9 (1): 36 40.

Achal V, Mukherjee A, Reddy M. 2011. Effect of calcifying bacteria on permeation properties of concrete structures. J Ind Microbio Biotechnol 38 (9): 1229-1234.

Ahmad A, Rautaray D, Sastry M. 2004. Biogenic calcium carbonate: calcite crystals of variable morphology by the reaction of aqueous $\mathrm{Ca} 2+$ ions with fungi. Adv Funct Mater 14: 1075-1080.

Alazhari M, Sharma T, Heath A, Cooper R, Paine K. 2018. Application of expanded perlite encapsulated bacteria and growth media for selfhealing concrete. Construction Building Mater 160: 610-619.

Algaifi HA, Bakar SA, Sam AR, Ismail M, Abidin AR, Shahir S, Altowayti WA. 2020. Insight into the role of microbial calcium carbonate and the factors involved in self-healing concrete. Construction Building Mater 254: 119258.

Alves L, Alves L, Mello M, Barros SD. 2019. Characterization of Bioconcrete and the Properties for Self-Healing. In: Multidisciplinary Digital Publishing Institute Proceedings 38 (1): 4-12.

Ameri F, Shoaei P, Bahrami N, Vaezi M, Ozbakkaloglu T. 2019 Optimum rice husk ash content and bacterial concentration in selfcompacting concrete. Construction Building Mater 222: 796-813.

Ataie FF. 2019. Influence of cementitious system composition on the retarding effects of borax and zinc oxide. Materials 12 (2019): 2340.

Babu NG, Siddiraju S. 2016. An experimental study on strength and fracture properties of self-healing concrete. Int J Civil Eng Technol 7 : 398-406.

Basheer L, Cleland DJ. 2011. Durability and water absorption properties of surface-treated concretes. Mater Struct 44: 957-967.

Basheer P, Basheer L, Cleland D, Long A. 1997. Surface treatments for concrete: assessment methods and reported performance. Construction Building Mater 11: 413-429.

Bashir J, Kathwari I, Tiwary A, Singh K. 2016. Bio concrete-the selfhealing concrete. Indian J Sci Technol 9: 1-5.

Bhaskar S, Hossain KM, Lachemi M, Wolfaardt G, Kroukamp M. 2017. Effect of self-healing on strength and durability of zeoliteimmobilized bacterial cementitious mortar composites. Cement Concrete Composites 82: 23-33.

Bhina MR, Salim M, Masroor MS. 2019. An overview on fungi as selfhealing agent in biomineralization of calcite. Int Res J Eng Technol 6 2980-2989.

Bindschedler S, Cailleau G, Verrecchia E. 2016. Role of fungi in the biomineralization of calcite. Minerals 6 (2): 41-59.

Bossio A, Lignola GP, Fabbrocino F, Monetta T, Prota A, Bellucci F, Manfredi G. 2017. Nondestructive assessment of corrosion of reinforcing bars through surface concrete cracks. Struct Concrete 18 (1): 104-117.

Castro-Alonso MJ, Montañez-Hernandez LE, Sanchez-Muñoz MA, Macias Franco MR, Narayanasamy R, Balagurusamy N. 2019. Microbially Induced Calcium carbonate Precipitation (MICP) and its potential in Bioconcrete: Microbiological and molecular concepts. Front Mater 6: 126. https://doi.org/10.3389/fmats.2019.00126

Chahal R. Siddique, A Rajor. 2012. Influence of bacteria on the compressive strength, water absorption and rapid chloride permeability of fly ash concrete. Construction Building Mater 28: 351-356.

Chaurasia L, Bisht V, Singh LP, Gupta S. 2019. A novel approach of biomineralization for improving micro and macro-properties of concrete. Construction Building Mater 195: 340-351.

Chen H, Qian C, Huang H. 2016. Self-healing cementitious materials based on bacteria and nutrients immobilized respectively. Construction Building Mater 126: 297-303.

Chen H-J, Peng C-F, Tang C-W, Chen Y-T. 2019. Self-healing concrete by biological substrate. Materials 12: 4099.

Cheng L, Cord-Ruwisch R. 2012. In situ soil cementation with ureolytic bacteria by surface percolation. Ecol Eng 42: 64-72.

Daba GM, Elkhateeb WA, Thomas PW. 2018. This era of biotechnological tools: an insight into endophytic mycobiota. Egypt Pharm J 17 (3): 121

Dai J-G, Akira Y, Wittmann F, Yokota H, Zhang P. 2010. Water repellent surface impregnation for extension of service life of reinforced concrete structures in marine environments: the role of cracks. Cement Concrete Composites 32: 101-109.

De Muynck W, Cox K, De Belie N, Verstraete W. 2008. Bacterial carbonate precipitation as an alternative surface treatment for concrete. Construction Building Mater 22: 875-885.

De Muynck W, De Belie N, Verstraete W. 2010. Microbial carbonate precipitation improves the durability of cementitious materials: a review. Ecol Eng 36: 118-36.

De Muynck W, Debrouwer D, De Belie N, Verstraete W. 2008. Bacterial carbonate precipitation improves the durability of cementitious materials. Cement Concrete Res 38: 1005-1014.

De Rooij M, Van Tittelboom K, De Belie N, Schlangen E. 2013. Selfhealing phenomena in cement-Based materials: state-of-the-art report of RILEM technical committee 221-SHC: self-Healing phenomena in cement-Based materials. Springer 2013

Decho AW. 2010. Overview of biopolymer-induced mineralization: what goes on in biofilms?. Ecol Eng 36 (2): 137-144.

Depaa R, Kala TF. 2018. An experimental study on fly ash as self-healing material. Int J Appl Eng Res 13: 5920-5925.

Dias MA, Lacerda IC, Pimentel PF, De Castro HF, Rosa CA. 2002. Removal of heavy metals by an Aspergillus terreus strain immobilized in a polyurethane matrix. Lett Appl Microbiol 34 (1): 46-50.

Dick J, De Windt W, De Graef B, Saveyn H, Van der Meeren P, De Belie N. 2006. Bio-deposition of a calcium carbonate layer on degraded limestone by Bacillus species. Biodegradation 17: 357-367.

Dinesh S, Shanmugapriyan R, Namitha S. 2017. A Review on BacteriaBased Self-Healing Concrete. Imperial J Interdiscip Res 3 (1): 24541362

Dry C. 1994. Matrix cracking repair and filling using active and passive modes for smart timed release of chemicals from fibers into cement matrices. Smart Mater Struct 3: 118-123.

Edvardsen C. 1999. Water permeability and autogenous healing of cracks in concrete. ACI Mater J 96: 448-454.

Elkhateeb WA, Daba GM. 2019. Myrothecium as promising model for biotechnological applications, potentials and challenges. Biomed J Sci Tech Res 16 (3): 12126-12131.

Ersan YC, De Belie N, Boon N. 2015. Microbially induced CaCO3 precipitation through denitrification: an optimization study in minimal nutrient environment. Biochem Eng J 101: 108-118.

Fang C, Kumari D, Zhu X, Achal V. 2018. Role of fungal-mediated mineralization in biocementation of sand and its improved compressive strength. Int Biodeterior Biodegrad 133: 216-220.

Gautam BR. 2018. Bacteria based self-healing concrete-a bacterial approach. Int J Eng Sci 57-61.

Gavimath C, Mali B, Hooli V, Mallpur J, Patil A, Gaddi D, Ternikar C, Ravishankera B. 2012. Potential application of bacteria to improve the strength of cement concrete. Int J Adv Biotechnol Res 3: 541-544.

Ghali A, Favre R, Elbadry M. 2018. Concrete structures: Stresses and deformations: Analysis and design for serviceability. CRC Press. 
Gharieb MM, Sayer JA, Gadd GM. 1998. Solubilization of natural gypsum (CaSO42H2O) and formation of calcium oxalate by Aspergillus niger and Serpula himantioides. Mycol Res 102: 825-830.

Ghosh P, Mandal S, Chattopadhyay B, Pal S. 2005. Use of microorganisms to improve the strength of cement mortar. Cement Concrete Res 35: 1980-1983.

Giannaros P, Kanellopoulos A, Al-Tabbaa A. 2016. Damage recovery in self-healing concrete. In: Proceedings of HealCon Conference, Delft, the Netherlands, 28-29 November 2016.

Girometta C, Picco A, Baiguera R, Dondi D, Babbini S, Cartabia M, Pellegrini M, Savino E. 2019. Physico-mechanical and thermodynamic properties of mycelium-based biocomposites: a view. Sustainability 11 (1): 281.

Harshali J, Mitali S, Neha A, Pragati B. 2016. Bio concrete and bacteriabased self-healing concrete. Int J Res Eng Technol 5: 95-99.

Hassoun MN, Al-Manaseer A. 2020. Structural concrete: theory and design. John Wiley \& Sons, New York.

Huang H, Ye G. 2015. Self-healing of cracks in cement paste affected by additional $\mathrm{Ca}^{2+}$ ions in the healing agent. J Intelligent Mater Syst Struct 26 (3): 309-320.

Ibrahim M, Al-Gahtani A, Maslehuddin M, Almusallam A. 1997. Effectiveness of concrete surface treatment materials in reducing chloride-induced reinforcement corrosion. Construction Building Mater 11: 443-451.

Isaacs B, Lark R, Jefferson T, Davies R, Dunn S. 2013. Crack healing of cementitious materials using shrinkable polymer tendons. Struct Concrete 14: 138-147.

Jagadeesha Kumar B, Prabhakara R, Pushpa H. 2013. Effect of bacteria calcite precipitation on compressive strength of mortar cubes. Int $\mathbf{J}$ Eng Adv Technol 2: 486-491.

Jiang L, Jia G, Jiang C, Li Z. 2020. Sugar-coated expanded perlite as a bacterial carrier for crack-healing concrete applications. Construction Building Mater 232: 117222.

Jin C, Yu R, Shui, Z. 2018. Fungi: A neglected candidate for the application of self-healing concrete. Front Built Environ 4 (62): 1-8. DOI: https://doi.org/10.3389/fbuil.2018.00062.

Jonkers H. 2007. Self healing concrete: a biological approach. In Selfhealing materials. Springer 195-204.

Jonkers HM. 2011. Bacteria-based self-healing concrete. Heron 56: 1-122.

Jonkers HM, Thijssen A, Muyzer G, Copuroglu O, Schlangen E. 2010 Application of bacteria as self-healing agent for the development of sustainable concrete. Ecol Eng 36: 230-235.

Joshi S, Goyal S, Mukherjee A, Reddy MS. 2017. Microbial healing of cracks in concrete: a review. J Ind Microbiol Biotechnol 44 (11): 1511-1525.

Kang C, Zhongxian J. 2012. Evaluation of autogenous healing ability of cementitious composites [Dissertation] Nagoya University (2012): 1-

Kavia K, Hema C. 2015. Dressing of structural cracks using Bio Concrete. Indian J Sci Technol 8: 1-4.

Khaliq W, Ehsan MB. 2016. Crack healing in concrete using various bio influenced self-healing techniques. Construction Building Mater 102: 349-357.

Krajewska B. 2018. Urease-aided calcium carbonate mineralization for engineering applications: A review. J Adv Res 13: 59-67.

Krishnapriya S, Babu DV. 2015. Isolation and identification of bacteria to improve the strength of concrete. Microbiol Res 174: 48-55.

Kumari B. 2015. Microbial concrete: A multi-purpose building materialAn overview. Int J Adv Eng Technol 7: 1608-1619.

Kumari D, Qian XY, Pan X, Achal V, Li Q, Gadd GM. 2016 Microbially-induced carbonate precipitation for immobilization of toxic metals. In: Advances in applied microbiology. Acad Press 94: 79-108.

Kunal Siddique R, Rajor A, Singh M. 2016. Influence of bacterial-treated cement kiln dust on strength and permeability of concrete. J Mater Civil Eng 28: 04016088

Li PH, Wang K, Wang ZJ. 2012. Remediation and improvement of concrete by bacterial mediated carbonate deposition. Adv Mater Res 3373-3376.

Li Q, Csetenyi L, Gadd GM. 2014. Biomineralization of metal carbonates by Neurospora crassa. Environ Sci Technol 48 (24): 14409-14416.

Li Q, Csetenyi L, Paton GI, Gadd GM. 2015. $\mathrm{CaCO}_{3}$ and $\mathrm{SrCO}_{3}$ bioprecipitation by fungi isolated from calcareous soil. Environ Microbiol 17 (8): 3082-3097.

Łukowski P, Adamczewski G. 2013. Self-repairing of polymer-cement concrete. Bull Polish Acad Sci. Tech Sci 61 (1): 195-200.
Luo J, Chen X, Crump J, Zhou H, Davies D, Zhou G, Jin C. 2018. Interactions of fungi with concrete: significant importance for biobased self-healing concrete. Construction Building Materials 164: 275-285.

Magan N. 2007. Fungi in extreme environments. The Mycota 4: 85-103.

Maheswaran S, Dasuru S, Murthy AR, Bhuvaneshwari B, Kumar V, Palani G, Iyer NR, Krishnamoorthy S, Sandhya S. 2014. Strength improvement studies using new type wild strain Bacillus cereus on cement mortar. Curr Sci 50-57.

Mamo G, Mattiasson B. 2019. Alkaliphiles: The emerging biological tools enhancing concrete durability. Springer 172: 293-342

Manikandan A, Padmavathi A. 2015. An experimental investigation on improvement of concrete serviceability by using bacterial mineral precipitation. Int J Res Sci Innov 2: 48.

Martuscelli C, Soares C, Camões A, Lima N. 2020. Potential of fungi for concrete repair. Proc Manufacturing 46: 180-185.

Medeiros M, Helene P. 2009. Surface treatment of reinforced concrete in marine environment: Influence on chloride diffusion coefficient and capillary water absorption. Construction Building Mater 23: 14761484.

Menon RR, Luo J, Chen X, Zhou H, Liu Z, Zhou G, Zhang N, Jin C. 2019. Screening of fungi for potential application of self-healing concrete. Sci Rep 9(1): 1-12.

Morsali S. Isildar G, Tahni A. 2019. The application of bacteria as a main factor in self-healing concrete technology. J Building Pathol Rehabil 4 (2019): 7.

Nama P, Jain A, Srivastava R, Bhatia Y. 2015. Study on causes of cracks $\&$ its preventive measures in concrete structures. Int J Eng Res Appl 5 (5): 119-123.

Neville AM. 1996. Properties of Concrete. Pearson Higher Education, New Jersey.

Nosouhian F, Mostofinejad D, Hasheminejad H. 2016. Concrete durability improvement in a sulfate environment using bacteria. J Mater Civil Eng 28 (1): 04015064.

Oggerin M, Tornos F, Rodriguez N, Pascual L, Amils R. 2016. Fungal iron biomineralization in Rio Tinto. Minerals 6 (2): 37-48.

Pal S, Mohanty I, Panda I. 2020. Self-healing conventional concrete using bacteria. In: Recent Developments in Sustainable Infrastructure. Springer, Singapore.

Pasquale V, Fiore S, Hlayem D, Lettino A, Huertas FJ, Chianese E, Dumontet S. 2019. Biomineralization of carbonates induced by the fungi Paecilomyces inflatus and Plectosphaerella cucumerina. Int Biodeterior Biodegrad 140: 57-66.

Povedano-Priego C, Martín-Sánchez I, Jroundi F, Sánchez-Castro I, Merroun ML. 2017. Fungal biomineralization of lead phosphates on the surface of lead metal. Minerals Eng 106: 46-54

Qian C, Zhou H, Wang K. 2019. Factors affecting morphology of microbially induced calcium carbonate. J Microbiol Exp 7 (2): 10114

Ramachandran SK, Ramakrishnan V, Bang S. 2001. Remediation of concrete using micro-organisms, ACI Mater J Am Concrete Inst 98: 3-9.

Ramakrishnan V, Deo K, Duke E, Bang S. 1999. SEM investigation of microbial calcite precipitation in cement. In: Proceedings of the International Conference on Cement Microscopy. Int Cement Microsc Assoc 406-414.

Rao M, Reddy S, Hafsa M, Veena P, Anusha P. 2013. Bioengineered concrete-a sustainable self-healing construction material. Res J Eng Sci 2278 (2013): 9472.

Rautaray D, Ahmad A, Sastry M. 2003. Biosynthesis of CaCO3 crystals of complex morphology using a fungus and an actinomycete. J Am Chem Soc 125: 14656-14657.

Rautaray D, Ahmad A, Sastry M. 2004. Biological synthesis of metal carbonate minerals using fungi and actinomycetes. J Mater Chem 14: 2333-2340.

Ravindranatha, Kannan N, Likhit ML. 2014. Self-healing material bacterial concrete. Int J Res Eng Technol 3n(3): 656-659.

Reddy V, Seshagiri Rao M, Sushma S. 2015. Feasibility Study on Bacterial Concrete as an innovative self crack healing system. Int J Mod Trends Eng Res 2: 642-647.

Reddy MS. 2013. Biomineralization of calcium carbonates and their engineered applications: a review. Front Microbiol 4: 314. DOI: https://doi.org/10.3389/fmicb.2013.00314

Roodman D, Lenssen N, Peterson J. 1995. A building revolution: how ecology and health concerns are transforming construction. Worldwatch Institute, Washington, DC. 
Ruan S, Qiu J, Weng Y, Yang Y, Yang E, Chu J, Unluer C. 2019. The use of microbial induced carbonate precipitation in healing cracks within reactive magnesia cement-based blends. Cement Concrete Res 115: 176-188.

Saifee S, Lad D, Juremalani J. 2015. Critical appraisal on Bacterial Concrete. IJRDO-J Mechanical Civil Eng 2456-1479.

Sayer JA, Kierans M, Gadd GM. 1997. Solubilisation of some naturally occurring metal-bearing minerals, limescale and lead phosphate by Aspergillus niger. FEMS Microbiol Lett 154: 29-35.

Seifan M, Samani A, Berenjian A. 2016. Bioconcrete: next generation of self-healing concrete. Appl Microbiol Biotechnol 100: 2591-2602.

Seifan M, Sarmah AK, Samani AK, Ebrahiminezhad A, Ghasemi Y, Berenjian A. 2018. Mechanical properties of bio self-healing concrete containing immobilized bacteria with iron oxide nanoparticles. Appl Microbiol Biotechnol 102 (10): 4489-4498.

Senthilkumar V, Palanisamy T, Vijayakumar V. 2014. Fortification of compressive strength in Enterococcus microorganisms incorporated microbial cement mortar. Int J Chem Tech Res 6: 636-644.

Setlow P. 1994. Mechanisms which contribute to the long-term survival of spores of Bacillus species. J Appl Bacteriol 76: 49S-60S.

Shaheen N, Khushnood R, Khaliq W, Murtaza H, Iqbal R, Khan M. 2019. Synthesis and characterization of bio-immobilized nano/micro iner and reactive additives for feasibility investigation in self-healing concrete. Construction Building Mater 226: 492-506.

Sharaky AM, Mohamed NS, Elmashad ME, Shredah N. 2018. Application of microbial biocementation to improve the physicomechanical properties of sandy soil. Construction Building Mater 190: 861-869.

Sheir DH, Amer O, Elkhateeb WA, Daba GM. 2020. Elucidation of mycodeterioration affecting calcareous construction materials of the Egyptian architectural heritage. Boreal Environ Res 25: 27-56.

Sidiq A, Gravina R, Giustozzi F. 2019. Is concrete healing really efficient? A review. Construction Building Mater 205: 257-273.

Silva F, Boon N, De Belie N, Verstraete W. 2015. Industrial application of biological self-healing concrete: challenges and economical feasibility. J Commercial Biotechnol 21 (1): 31-38.

Sisomphon K, Copuroglu O, Koenders E. 2012. Self-healing of surface cracks in mortars with expansive additive and crystalline additive. Cement Concrete Composites 34: 566-574.

Stanaszek-Tomal E, Kozak A. 2017. Mineral and organic coatings modified nano-TiO2 addition as elements of sustainable building. Sustainability 1-10.

Stanaszek-Tomal E. 2020. Bacterial concrete as a sustainable building material? Sustainability 12: 696-670.

Ter Heide N, Schlangen E. 2007. Self-healing of early age cracks in concrete. In: First international conference on self-healing materials $1-12$
Ter Heide N. 2005. Crack healing in hydrating concrete. Delft University of Technology 12-82.

Van Tittelboom K, De Belie N, De Muynck W, Verstraete W. 2010. Use of bacteria to repair cracks in concrete. Cement Concrete Res 40: 157166.

Vekariya MS, Pitroda J. 2013. Bacterial concrete: new era for construction industry. Int J Eng Trends Technol 4 (9): 4128-4137.

Verrecchia EP. 2000. Fungi and sediments. In: Riding RE, Awramik SM (eds) Microbial Sediments. Springer-Verlag, Berlin.

Vijay K, Murmu M. Deo S. 2017. Bacteria based self-healing concrete-A review. Construction Building Mater 152: 1008-1014.

Vinoth T, Rahimunissa A, Manikandeswari S, Valavan E, Vadivel P, Thangam D. 2016. Causes and remedies on concrete cracks-A review. Int J Eng Manag Res 6 (5): 550-551.

Waghmode MS, Gunjal AB, Bhujbal NN, Patil NN, Nawani NN. 2019. Eco-Friendly Construction. In: Reusable and Sustainable Building Materials in Modern Architecture. IGI Global, America.

Wang J, Dewanckele J, Cnudde V, Van Vlierberghe S, Verstraete W, De Belie N. 2014. X-ray computed tomography proof of bacterial-based self-healing in concrete. Cement Concrete Composites 53: 289-304.

Wang J, Van Tittelboom K, De Belie N, Verstraete W. 2010. Potential of applying bacteria to heal cracks in concrete. In: Proceedings of the second international conference on sustainable construction materials and technologies: 1807-1818.

Wang JY, De Belie N, Verstraete W. 2012. Diatomaceous earth as a protective vehicle for bacteria applied for self-healing concrete. J Ind Microbiol Biotechnol 39: 567-577.

Yang Y, Ma L, Huang J, Gu C, Xu Z, Liu J, Ni T. 2019. Evaluation of the thermal and shrinkage stresses in restrained high-performance concrete. Materials 12 (2019): 3680.

Yang G, Gu C, Bao T, Cui Z, Kan K. 2016. Research on early-warning index of the spatial temperature field in concrete dams. SpringerPlus 5 (2016): 1968.

Žáková H, Pazderka J, Rácová Z, Ryparová P. 2019. Effect of bacteria bacillus pseudofirmus and fungus Trichoderma reesei on self-healing ability of concrete. Acta Polytechnica CTU Proc 21: 45-45.

Zhang J, Liu Y, Feng T, Zhou M, Zhao L, Zhou A. 2017. Immobilizing bacteria in expanded perlite for the crack self-healing in concrete. Construction Building Mater 148: 610-617.

Zhang X. Qian C. 2020. Engineering application of microbial self-healing concrete in lock channel wall. Case Stud Construction Mater (2020): e00398.

Zhu T, Dittrich M. 2016. Carbonate precipitation through microbial activities in natural environment, and their potential in biotechnology: a review. Front Bioeng Biotechnol 4: 4-25. DOI: https://doi.org/10.3389/fbioe.2016.00004 